\title{
ІНФОРМАЦІЙНА ПЛАТФОРМА ЗАБЕЗПЕЧЕННЯ БЕЗПЕКИ ПАЦІЄНТІВ
}

\author{
О. П. Мінцер, П. Мієржевський, В. Г. Сердюк, С. В. Денисенко,
} Л. Ю. Бабінцева

\author{
Національна медична академія післядипломної освіти імені П. ^. Шупика
}

\begin{abstract}
Розглянуті основні проблеми забезпечення безпеки пацієнта. Підкреслюється думка, що основою безпеки пацієнта $€$ не лише строге забезпечення якості медичної допомоги, але і повне його інформування про можливі ризики лікування, максимально повний і комплексний облік чинників ризику, ідентифікації небезпеки і, нарешті, обґрунтований процес ухвалення рішення про стратегію діагностики і лікування. При обговоренні логіки оцінювання якості медичної допомоги акцент робиться на якомога повнішому застосуванні індустріальних методів.
\end{abstract}

Ключові слова: безпека пацієнта, інформована згода, причини медичних помилок, якість медичної допомоги, незадоволення пацієнта, чинники ризику, ідентифікація небезпеки.

\section{ИНФОРМАЦИОННАЯ ПЛАТФОРМА ОБЕСПЕЧЕНИЯ БЕЗОПАСНОСТИ ПАЦИЕНТОВ}

\author{
О. П. Минцер, П. Миержевский, В. Г. Сердюк, С. В. Денисенко, \\ Л.Ю. Бабинцева
}

Национальная медицинская академия последипломного образования имени П. А. Шупика

\begin{abstract}
Рассмотрены основные проблемы обеспечения безопасности пациента. Подчеркивается мысль, что основой безопасности пациента является не только строгое обеспечение качества медицинской помощи, но и полное информирование пациента о возможных рисках лечения, максимально полный и комплексный учет факторов риска, идентификации опасности и, наконец, обоснованный процесс принятия решения о стратегии диагностики и лечения. При обсуждении логики оценки качества медицинской помощи акцент делается на возможно полное применение индустриальных методов.
\end{abstract}

Ключевые слова: безопасность пациента, информированное согласие, причины медицинских ошибок, качество медицинской помощи, неудовлетворенность пациента, факторы риска, идентификация опасности.

\section{INFORMATION PLATFORM FOR SECURING OF PATIENT'S SAFETY}

\section{O. P. Mintser, P. Myerzhevskyi, V. H. Serdiuk, S. V. Denysenko, L.Yu. Babyntseva National Medical Academy of Post-Graduate Education by P. L. Shupyk}

\begin{abstract}
The main problems of patient's safety securing are discussed. It is emphasized the idea that the basis of the patient's safety is not only to provide the quality of medical care, but to fully inform the patient ab out the possible risks of treatment, the most comprehensive and integrated risk management, hazard identification, and finally, reasonable diagnosis and treatment strategies decisions. In discussing the logic evaluation of quality of care it is focused on the possible full application of industrial methods.
\end{abstract}

Key words: patient's safety, the structure of the causes of incidents, informed consent, identification of the causes of medical errors, quality of care, patient's dissatisfaction, risk factors, identification of hazards.

Вступ. Забезпечення безпеки - одна з актуальних проблем медицини, важливих для глобальної охорони здоров'я. Аналітичний процес зі зниження рівня небезпеки від медичних дій можна представити як проблему, що складається із чотирьох основних частин: формалізації завдань, термінів, класифікацій; стратегічних питань оцінювання якості медичної до(C) О. П. Минцер, П. Миержевский, В. Г. Сердюк та ін. помоги; оцінювання ризиків ускладнень у процесі лікування, їх моніторингу, ідентифікації небезпеки; виявленню й аналізу помилок у діагностиці та лікуванні пацієнтів.

Мета роботи полягає у концептуальному проробленні стратегії забезпечення безпеки пацієнтів у сучасних умовах діагностики та лікування. 


\section{Результати та їх обговорення. \\ 1. Формалізація завдань, термінів, класифі- кацій}

Під безпекою пацієнтів розуміли максимально можливу відповідність клінічних результатів наявним даним про ефективність надання медичної допомоги, очікуванням лікаря та пацієнта при мінімальному ризику небажаних наслідків (ускладнень) [2].

Сьогодні попередньо та концептуально виділена структура факторів для визначення інцидентів при діагностиці та лікуванні пацієнтів. У міжнародній класифікації безпеки пацієнтів (International Classification of Patient Safety - ICPS) виділені 10 рівнів (вищих пріоритетів): 1. Тип інциденту. 2. Результат лікування пацієнта. 3. Характеристики пацієнта. 4. Характеристики інциденту. 5. Діючі чинники / ризики. 6. Організаційні висновки. 7. Детекція (розслідування). 8. Чинники поліпшення. 9. Дії з поліпшення стану. 10. Зроблені дії зі зменшення ризику.

Ця класифікація детально наведена в різних технічних додатках до міжнародних документів [6].

Класифікація наступного рівня містить 48 основних (ключових) концептів. Вони визначені та виділені як переважні терміни для поліпшення розуміння і передачі інформації для забезпечення безпеки пацієнта. Ці концепти представлені як стартові для подальшого прогресивного поліпшення загального міжнародного розуміння термінів і концептів відносно безпеки пацієнта.

Водночас концептуальна база (ICPS) має бути ретельніше обгрунтована, передусім, для визначення методів і підходів для створення системи безпеки пацієнтів. Вона стосується даних та інформації, що мають бути агреговані та пристосовані для аналізу: методів міждисциплінарного, міжпрофесійного порівняння даних про пацієнтів незалежно від часу та кордонів; оцінювання ролі системи та людського чинника в забезпеченні безпеки пацієнта; методів ідентифікації особливостей пацієнта, розвитку пріоритетних чинників і рішення проблем безпеки пацієнта.

\section{2. Елементи теоії забезпечення безпеки па- цієнта}

До основних структурних складових безпеки пацієнтів у багатопрофільному медичному закладі зазвичай відносять ускладнення після медичних втручань, психологічні конфлікти, незадоволення пацієнта медичною допомогою.

Ускладненням медичного втручання вважають будь-яке погіршення стану хворого на етапі стаціонарного лікування: ускладнення після медикаментозної терапії, медичних маніпуляцій, діагностичних і параклінічних лікувальних втручань і ускладнення основного захворювання, що розвинулися після початку лікування в стаціонарі.

Психологічні конфлікти розглядаються як ті, що розвинулися безпосередньо між пацієнтом і лікарем, хворим і середнім медичним працівником тощо.

Під кількісною оцінкою "незадоволення пацієнтів" розуміють частку хворих, які негативно характеризують хоч би одну зі сторін лікувально-діагностичного процесу. При цьому до уваги береться незадоволення пацієнта доступністю, перебігом або результатом лікувально-діагностичного процесу.

Поняття "незадоволення пацієнта" дуже часто проявляється в стаціонарах при використанні нових технологій. Так, наприклад, в клініці використання методів екстракорпорального запліднення проблема нерозуміння основних труднощів і ризиків часто призводить до незадоволення пацієнта.

Теорія та практика забезпечення безпеки пацієнта безпосередньо пов'язана з оцінюванням якості медичної допомоги (ЯМД).

3. Існуючі системи оцінки якості надання медичної допомоги

Європейське бюро ВОО3 у звіті, присвяченому формуванню принципів забезпечення ЯМД, вказало на необхідність при вирішенні даної проблеми враховувати чотири елементи [9]: кваліфікацію спеціаліста; оптимальність використання ресурсів; ризик для пацієнта; задоволеність пацієнта від взаємодії з медичною підсистемою.

Сучасні європейські принципи забезпечення якості спираються на позиціонування ролі пацієнта в забезпечені його безпеки, а також на ефективність, раціональність, справедливість і вчасність надання медичної допомоги. Тому обгрунтування управління системою оцінювання якості надання медичної допомоги базується на забезпеченні прав пацієнтів на одержання медичної допомоги у необхідному обсязі і належної якості.

Управління якістю медичної допомоги включає вдосконалення структури процесу, безпосередньо самого процесу та результату надання медичної допомоги (тріада Донабедіана, 1996). При цьому передбачається управління трьома складовими, а саме: 1) аналіз професійних навичок лікаря, забезпеченість апаратурою та медперсоналом, оцінка умов організації та фінансування, що в сукупності характеризує якість структури; 2) оцінювання діагностичних і лікувальних заходів, тобто якість процесу; 3) аналіз якості результатів.

В узагальненому розумінні існують три основні моделі управління якістю медичної допомоги. Це 
професійна модель, що визначається кваліфікаційними характеристиками лікаря, які забезпечують рівень і гарантію якості надання медичної допомоги. При цьому професійні характеристики лікаря визначаються шляхом експертної оцінки, анкетуванням колег i пацієнтів, тестуванням та іншими методами. Друга модель - бюрократична, що базується на ієрархічному методі управління, використовує аудиторський принцип та методи статистичного аналізу.

Показниками якості служать досягнення оптимального результату, відповідність стандартам, низькі показники летальності тощо. Запропонована низка методів, таких як цикл Демінга (метод вибіркового статистичного контролю), використання абсолютного та відносного ризиків розвитку подій, розрахунок кількості пацієнтів, яких слід пролікувати для отримання одного позитивного результату. Всі вони були спрямовані на об'єктивну оцінку функціонування бюрократичної моделі.

Третя модель управління якістю медичної допомоги - індустріальна - передбачає використання адаптованого до умов охорони здоров'я алгоритму безперервного підвищення якості. В цій моделі розглядаються такі інструменти як діаграма Ішікави, діаграма Парето, діаграма розсіяння, контрольна діаграма та інші.

Сучасні системи оцінювання ЯМД використовують переважно індикатори, серед яких розглядаються:

- визначення компонентів високоякісної медичної допомоги;

- визначення відповідальних за якість допомоги, особливо у випадках, коли пацієнти користуються послугами декількох медичних установ, організацій $і$ лікарів;

- оцінка прогнозованих результатів і пріоритетів, що визначаються лікарями, пацієнтами, страховими компаніями та адміністрацією;

- розробка та використання ефективних методів проведення безперервного контролю, оцінювання та поліпшення якості в кожній установі системи охорони здоров'я;

- формування умов для підвищення якості медичної допомоги;

- формування системи контролю якості медичної допомоги;

- прийняття управлінських рішень, що спрямовані на підвищення ефективності та якості медичної допомоги [4].

Використання ретельно підібраних індикаторів i порогів для оцінювання - це важливі частини процесу надання якісної медичної допомоги, але індикатор сам по собі не визначає рівня якості. Індикатори лише визначають потенційні проблеми. Вкрай важливо підкреслити, що в дійсності реальну якість надання медичної допомоги можуть оцінити лише функціонали та критерії.

Інший підхід запропоновано Г.І. Лисенко і В. О. Мінцер [5] на прикладі роботи сімейного лікаря. Якість роботи сімейного лікаря визначається насамперед показниками здоров'я закріпленого контингенту пацієнтів. Автори запропонували в оцінці ЯМД сімейного лікаря використовувати динаміку низки показників, які можуть бути отримані під час моніторингу, а саме:

Результативність - міра досягнення цілей лікування. Результативність можна визначити як відношення досягнутого до максимально можливого результату, що базується на використанні останніх досягнень науки та технологій. Для оцінки результативності медичної допомоги використовують три групи показників: медичні: а) загальні та спеціальні показники (для конкретних спеціальностей); б) економічні показники ефективності роботи: в цілому, інвестиційних програм, фінансування, використання коштів; в) соціальні: мікросоціальні (задоволеність якістю медичної допомоги) i макросоціальні (рівні смертності, народжуваності, середня тривалість життя).

Ефективність - економічність, міра найраціональнішого використання ресурсів, тобто найменша вартість медичної допомоги без погіршення ії результативності. Ефективність є наслідком того, що "вірно виконуються правильні процедури".

Оптимальність - співвідношення витрат на охорону здоров'я й отриманих результатів лікування.

Прийнятність - відповідність наданої допомоги сподіванням, побажанням та надіям пацієнтів та їх родичів.

Законність - відповідність нормам, що визначені етичними принципами, законами, нормами та правилами.

Справедливість - відповідність принципу, що визначає обгрунтованість та законність розподілу медичної допомоги та пільг серед населення.

Під час контролю ЯМД оцінюються три основних компоненти цієї якості: структурний, процесний (технологічний) і кінцевий результат.

Групи показників ЯМД для конкретного пацієнта включають своєчасність, наступність, кваліфікацію медперсоналу, економічну ефективність, деонтологію.

4. Оцінювання ризиків ускладнень у процесі лікування, їх моніторинг, ідентифікація безпеки

Визначення факторів ризику (ФР) є необхідним для визначення стратегії ведення пацієнтів, тактики медикаментозного втручання, моніторингу стану. Од- 
нак інтегральну характеристику рівня ризику у конкретного пацієнта визначають не тільки ФР, а й багатьма індивідуальними особливостями, які необхідно враховувати при формуванні відповідних профілактичних програм.

На практиці, у пацієнтів часто наявні 2-3 ФР і більше. Але навіть якщо рівень кожного з ФР лише помірно підвищений, ризик розвитку ускладнень у цього пацієнта може бути високим внаслідок кумулятивного впливу цих факторів один на одного. Зауважимо, що комплексний облік ФР часто називають сумарним ризиком.

Сьогодні оцінювання сумарного ризику стає необхідною умовою оцінювання вірогідності розвитку ускладнень при лікуванні хворого для обгрунтування тактики управління цим ризиком шляхом клінічних і профілактичних втручань. Для цього необхідне визначення індивідуального профілю ФР і сумарного ризику, що впливає на прогноз у конкретного пацієнта.

Для оцінювання сумарного ризику розвитку ускладнень лікування розроблено багато моделей. Вони використовують як суто математичні підходи, так i чисто статистичні чи експертні.

Зауважимо, що чим простіша шкала факторів ризику, тим більшу популярність вона отримує серед лікарів та хворих. В той же час на базі простих рішень можна розглядати наступні процедури з більш точними ознаками ризиків.

Проілюструємо логіку використання оцінювання ризиків на прикладі серцево-судинних захворювань. Вважають, що першою з них була Фремінгемська шкала. Фремінгемське дослідження було першою успішною спробою створення концепції факторів ризику серцево-судинних захворювань на основі тривалого періоду спостережень і масштабності включення різних етнічних груп. Спостереження за кожним пацієнтом проводять кожні 2-4 роки впродовж 30 років із реєстрацією випадків кардіоваскулярних подій.

На наступних етапах результати досліджень використовують для розроблення математичних виразів (рівнянь) ризиків, що широко застосовуються для прогнозу ризику ішемічної хворобі серця (IXC). У Фремінгемському дослідженні для визначення сумарного ризику на найближчі 10 років використовується математичний алгоритм, де враховуються змінні величини наступних факторів ризику: вік, стать, паління, наявність IXC, рівень загального холестерину, систолічний артеріальний тиск тощо.

Найбільше поширення отримала схема у вигляді «квадратів», що враховує сумарний ризик у даного хворого.
Надзвичайно важливо підкреслити, що автори Фремінгемської шкали неодноразово акцентували увагу на тому, що результати оцінки ризику за нею необхідно екстраполювати на інші популяції з обережністю у зв'язку з наявністю регіональних, етнічних та інших особливостей формування захворювань у різних країнах.

\section{1. Управління ризиками. Ідентифікація не-}

\section{безпеки}

Управління ризиком є логічним продовженням оцінювання ризику та спрямоване на обгрунтування найкращих у даній ситуації рішень з його усунення або мінімізації, а також динамічного контролю (моніторингу) експозицій і ризиків, оцінці ефективності й коректуванню оздоровчих заходів. Управління ризиком базується на сукупності медичних та економічних оцінок отриманих величин ризику, порівняльній характеристиці можливих збитків для здоров'я, можливих витрат на реалізацію різних варіантів управлінських рішень зі зниження ризику й тих вигод, що будуть отримані в результаті реалізації заходів (наприклад, зменшення числа ускладнень при лікуванні тощо).

Порівняльна характеристика ризиків не дозволяє вирішити питання про їхню значимість і прийнятність. При аналізі прийнятності ризику враховують вигоди від використання лікувального засобу, заміни його іншим лікарським засобом тощо; можливість здійснення контролюючих (регулюючих) заходів із метою зменшення потенційного негативного впливу фактора ризику на здоров'я пацієнтів із факторами ризику виникнення ускладнень. Стратегія контролю рівнів ризику передбачає заходи, які найбільше сприяють мінімізації або усуненню ризику. Такі типові заходи можуть включати обмеження впливу факторів ризику або повне їх усунення.

У завдання управління ризиком входить також вибір стратегії динамічного (періодичного або постійного) моніторингу експозицій і ризиків. Дані види моніторингу виконують такі функції: контрольну (порівняння із гранично припустимими або прийнятними рівнями), сигнальну (швидке реагування на виникнення небезпечної ситуації), прогностичну (можливість прогнозування ризиків на основі аналізу тимчасових тенденцій), інструментальну (як засіб для розпізнавання й класифікації спостережуваних явищ).

Моніторинг експозицій і ризиків, заснований на результатах оцінювання ризику для здоров'я, є ефективним способом проведення спостереження за хворими. Якщо в групі факторів ризику, що піддаються корекції, отримано позитивні результати та існує можливість переводу цих хворих до нижчої групи ризику, 
слід обмежитися лише рекомендаціями, які зазвичай надаються хворим другої групи. В іншому випадку пропонуємо користуватися принципами системи ідентифікаџї небезпеки. Підкреслимо, що ідентифікація небезпеки є не тільки початковим, але й ключовим етапом оцінки ризику. На етапі ідентифікації небезпеки мають бути визначені граничні оцінки ризику.

Беручи до уваги виняткову значимість етапу ідентифікації небезпеки, вважаємо доцільним проводити його в три етапи.

На першому проводиться оцінювання існуючих (визначених) факторів ризику. Другий етап присвячується оцінюванню факторів ризику, що прогнозуються за даними моніторингу. Третій - основний полягає в зіставленні існуючих і прогнозованих факторів. Саме він дає можливість визначити валідність клінічних даних. Головним при цьому слід вважати ідентифікацію закономірностей першого та другого етапів шляхом зіставлення аналізу факторів ризику і інших показників здоров'я.

Активна оцінка стану хворого незалежно від його клінічного плану, по суті, являє собою ідентифікацію невиявленого ускладнення за допомогою тест-досліджень.

4.2. Прогнозування виникнення ускладнень. Логіка управління ризиками

Часто використовують підхід, який базується на обчисленні інтегральної оцінки ризику захворювання за наявними факторами із обгрунтованим критичним числом - так званим «порогом для прийняття рішень». Дослідження показали, що для хворих характерним є сукупність більшого числа присутніх факторів, тоді як у контрольній групі в наявності частіше один або два фактори ризику. Таке рішення грунтується на тому, що при певній кількості факторів ризику ймовірність ускладнень захворювання перебільшує подібну ймовірність у контрольній групі.

Зауважимо, що перетинання частотних кривих різного кількісного поєднання факторів при графічному порівняльному аналізі у пацієнтів 3 факторами ризику та здорових людей припадає на 3-5 факторів ризику.

\section{5. Виявлення й аналіз помилок у діагностиці та лікуванні паціснтів}

Одним із основних принципів є акцентування не на позитивних сторонах своєї роботи, а на бажаному поліпшенні. Відправною точкою в цьому випадку зазвичай $є$ виявлена й ідентифікована фахівцем проблема. А необхідною умовою їі вирішення є визначення й усунення її головної причини. Тільки в цьому ви- падку можна бути впевненим, що проблема буде дійсно розв'язана.

У подібних завданнях використовують підхід, який називається аналізом головної причини. Серед конкретних алгоритмів розглядають застосування логіки тестування й оцінювання пропозицій до прийняття остаточного рішення. Інші роблять акцент на залучення до процесу вирішення проблеми тих, хто знає їі найкраще. Треті вказують на важливість розгляду процесу вирішення проблеми як частини загального процесу поліпшень. Ще одним широко відомим підходом є колесо Демінга або цикл "плануй - виконуй-перевіряй - дій".

Колесо Демінга демонструє систематичний і безперервний підхід до вирішення проблеми. За чотири етапи проблема аналізується, вживаються коригувальні заходи, оцінюється результативність цих заходів і процес модернізується шляхом впровадження заходів, які дають бажаний результат.

У загальному випадку виявлення основної причини лікарських помилок розглядається у 6 етапів: ідентифікація проблеми; формулювання проблеми; усвідомлення проблеми; ідентифікація головної причини; усунення головної причини; моніторинг симптомів.

У свою чергу, в ідентифікації проблеми розглядається метод "блок-схем". Останній представляє комплекс дій, що включає складання спеціальної діаграми для відображення лікувально-діагностичного процесу; обгрунтування критичного етапу лікування (аналіз найбільш критичного етапу в лікуванні пацієнта); складання радарної діаграми (діаграма для проведення порівняльного аналізу можливих дій лікаря); використання матриці впливу для визначення причин виникнення небажаних наслідків.

При здійсненні пошуку вірогідної причини небажаних дій лікаря і досягнення консенсусу дуже часто застосовують методи "мозкового штурму", що є формалізованим підходом, застосовним на усіх етапах аналізу головної причини. Відомі також його різновиди, зокрема, "письмовий мозковий штурм" (мозковий штурм у письмовому виконанні); "метод формальної групи (метод, який використовують, щоб допомогти групі розставити за пріоритетами альтернативні варіанти); "попарне порівняння" (метод, використовуваний для досягнення консенсусу шляхом вибору одного $з$ двох варіантів кожним членом групи).

Кожен із етапів, присвячених обгрунтуванню проблем виникнення небажаних ускладнень у процесі діагностики та лікування пацієнтів, формалізований і припускає виконання цілого ряду етапів. Приміром, збір інформації про причини лікарських помилок складається $з 9$ етапів: 
- підготовки відповідної вибірки для проведення аналізу;

- проведення опитування зацікавлених персон для збору інформації про думку або ставлення персоналу;

- складання перевірочних листів;

- складання гістограм для виявлення тенденцій або аномалій;

- застосування діаграми Парето для демонстрації того, яка з причин чинить найбільший вплив;

- використання діаграми розсіювання для представлення взаємозв'язку між парами причин або інших параметрів, пов'язаних з проблемою, що вивчається;

- застосування діаграми залежностей для ідентифікації логічних взаємозв'язків між різними ідеями або питаннями, пов'язаними з аналізованою проблемою;

- використання аффіної діаграми для виявлення зв'язків між, здавалося б, незалежними ідеями, причинами.

Деякі роз'яснення необхідні в обгрунтуванні інструментарію аналізу.

Нині широко використовують метод складання "причинно-наслідкової діаграми" для аналізу можливих причин проблеми; "матричної діаграми" для впорядковування інформації до різного виду; метод "П'ять чому" для поглибленого вивчення взаємозв'язків між причинами тощо.

Блок-схеми та критичний випадок допомагають зрозуміти проблему зсередини. При необхідності зробити зовнішнє порівняння корисним інструментом може бути радарна діаграма. Головне ії призначення - дати графічне уявлення про рівень функціонування бізнес-процесу (чи проблемної області) порівняно 3 іншими організаціями.

Слід підкреслити, що метод "радарна діаграма", взагалі кажучи, є одним із видів бенчмаркингу. Бенчмаркинг означає порівняння рівнів функціонування або діяльності клінічною установою з більш високим рівнем. Таке порівняння має різні цілі, наприклад: створення мотивації модернізації шляхом інформування про інші технології або методи рішення задачі; отримання даних для визначення цільових показників процесу вирішення проблеми або інших дій, спрямованих на поліпшення тощо.

У рамках аналізу головної причини несприятливого результату або лікарської помилки основна логіка застосування радарної діаграми зводиться до визначення того, яка проблема є важливішою, а також порівняння рівнів серйозності проблем і причин.
У проведенні бенчмаркингу може допомогти використання радарної діаграми, оскільки вона дозволяє порівняти рівень різних процесів або галузей діяльності. На основі отриманих результатів, організація отримає уявлення про галузі, де поліпшення найпотрібніше.

Хоча аналіз головної причини небажаних наслідків діагностики і лікування хворого не є простим і чітко сформульованим процесом, деякі його етапи можуть бути конкретно визначені. Важливо оцінити, чи були виконані найбільш важливі елементи етапу визначення проблеми. Зокрема, до початку аналізу головної причини важливо досягти згоди відносно проблем, які необхідно вирішувати.

Часто вже заздалегідь існує припущення відносно причини проблеми, яку належить вирішувати. Проте, у будь-якому випадку потрібні строгіші методи пошуку вірогідної причини. Важливо також мати набір інструментів, що допомагають прийти до єдиної думки у випадку розбіжностей.

У літературі описана велика кількість підходів, які використовують на цьому етапі. Вони включають: мозковий штурм; письмовий мозковий штурм; метод формальної групи; метод попарного порівняння.

Існують і інші методи, які теж грунтуються на принципі вибору серед двох або більшої кількості варіантів або ідей з отриманням у результаті списку за пріоритетом. Так, широко застосовуються: метод розрахунку "балансу", в якому обчислюється число "за і проти" альтернативних рішень; метод "оцінки за критерієм" - числовий підхід, що використовує певний критерій відносно набору ідей для їх оцінювання; метод "зваженого голосування" тощо.

Останнім часом поширення отримали методики структурного аналізу, що можуть як окремо, так і в різних комбінаціях застосовуватися для пошуку кореневих причин інцидентів.

Найбільш відома методика отримала назву методу структурного аналізу причинно-наслідкових зв'язків, або діаграми Ішікави.

Цінність цього методу полягає у сприянні категоризації і структуризації безлічі потенційних причин, а також ідентифікації найбільш вірогідної кореневої причини наслідку, який вивчається. Метод застосовний при виконанні аналізу як одним фахівцем, так і групою фахівців.

Основною перевагою цього методу є його наочність і універсальність. Наочність досягається за рахунок того, що зв'язок усіх виявлених причин із досліджуваним наслідком відображається у простій графічній формі. 
До обмежень можна віднести необхідність попереднього пошуку можливих причин досліджуваного наслідку, а так само складність (не точність) при визначенні міри впливу виявлених причин на вірогідність виникнення наслідку.

Підвищення клінічної результативності лікувальнодіагностичного процесу після впровадження комплексної системи забезпечення безпеки пацієнтів безпосередньо корелює зі зменшенням числа ускладнень медичних втручань, тривалих госпіталізацій і незапланованих регоспіталізацій, переводів у інші відділення $з$ приводу ускладнень втручань, частоти розвитку внутрішньолікарняної інфекції.

Після впровадження комплексної системи забезпечення безпеки пацієнтів, за даними літератури, збільшується частка хворих, повністю задоволених лікуванням (включаючи оцінювання за трьома категоріями: доступність лікувально-діагностичного процесу, власне лікувально-діагностичний процес і його результат).

При цьому відзначається збільшення тих, хто бажає повторно звернутися за медичною допомогою в той же заклад.

Висновки. 1. Має бути поетапно впроваджена комплексна система забезпечення безпеки пацієнтів у багатопрофільному медичному закладі.

2. До числа основних структурних складових безпеки пацієнтів у багатопрофільному закладі слід включити також профілактику ускладнень медичних втручань.

3. Психологічні конфлікти, незадоволення пацієнта медичною допомогою, небажання пацієнта подовжити лікування пов'язані, передусім, із дефектами в організації роботи медичного персоналу.

4. Основою профілактики дефектів організації роботи медичного персоналу є впровадження індустріальних технологій управління якістю медичної допомоги, грунтованих на процесному аналізі, стратегічному плануванні, безперервному вдосконаленні лікувально-діагностичного процесу. Базисним напрямом при впровадженні індустріальних методів управління є використання структурного аналізу.

5. Основним етапом визначення головної причини медичної помилки та виникнення небажаних наслідків діагностики і лікування хворого є оцінка виконання найбільш важливих елементів лікувального процесу.

6. Для запобігання ускладненням медичних втручань рекомендується в кожній лікувально-профілактичній установі впровадження медичних технологій iз доведеною клінічною ефективністю та навчання персоналу основ доказової медичної практики.

7. Для профілактики відхилень, обумовлених поведінкою хворого, необхідно використовувати систему відкритого та грунтовного інформування хворого і його родичів про характер захворювання, переваги та недоліки альтернативних методів лікування.

\section{Література}

1. Индустриальные методы управления качеством медицинской помощи в амбулаторно-поликлиническом учреждении / [Кучеренко В. З., Вардосанидзе С. Л., Восканян Ю. Э. [и др.] // Методические рекомендации МЗ РФ. - № 2003/ 110. - М., 2003. - 56 c.

2. Измерение лечебно-диагностического процесса в условиях многопрофильной больницы / Вардосанидзе С. Л., Восканян Ю. Э., Кошель В. И. [и др.] // Менеджер здравоохранения. - 2004. - №> 11. - С. 42-47.

3. Шикина И. Б. Пути обеспечения безопасности пациентов в многопрофильном стационарном лечебно-про филактическом учреждении / И. Б. Шикина // Пособие для организаторов здравоохранения. - М., 2006. - 36 с.

4. Котляревський Ю. О. Механізм формування цінової оцінки медичної послуги / Ю. О. Котляревський // Менед-

жер : вісник Донецького державного університету управління. - 2006. - №> 2 (36). - С. 62 - 65.

5. Лисенко Г. І. Концепція та логіка вирішення задач сімейної медицини / Г. І. Лисенко, В. О. Мінцер // Сімейна медицина. - 2006. - №> 4 (18). - С. 9-10.

6. http://www.who.int/patientsafety/implementation/ taxonomy/en/.

7. http://www.who.int/patientsafety/implementation/ taxonomy/conceptual_framework/en/index.html.

8. Towards an International Classification for Patient Safety: key concepts and terms / W. Runciman, P. Hibbert, R. Thomson [et al.] // Int. J. Qual. Health Care. - 2009. Vol. 21: - P. 18-26.

9. Assuring the quality of health care in the European Union http://www.euro.who.int/ data/assets/pdf file/0007/98233/ E91397.pdf. 